\title{
Reflective Practice Research in Teacher EDUCATION
}

\author{
INVESTIGACIÓN DE PRÁCTICA REFLEXIONADA EN LA \\ EDUCACIÓN DE MAESTROS
}

\author{
MichAEL NOAH WEISS \\ University of South-Eastern Norway \\ Norway \\ michael.weiss@usn.no \\ ORCID: https://orcid.org/0000-0002-3471-7697
}

RECEIVED: JULY, 15, 2020

ACCEPTED: NOVEMBER, 19, 2020

\begin{abstract}
In this essay the approach of reflective practice research, as introduced by the philosopher Anders Lindseth, is outlined and its relevance for teacher education is discussed. For that purpose, central theoretical as well as methodological aspects of this research approach are presented and further investigated. By means of illustrative case studies, examples are given on how this approach can be of use for teacher students in order to develop research competence, on the one hand. On the other, this essay examines how a teacher can reflect his or her own practice, in terms of self-studies, in order to learn from experience and to develop towards so-called phronesis (practical wisdom or prudence).
\end{abstract}

Keywords: Reflective practice research, teacher education, teacher student, philosophical practice, phronesis

Resumen: En este artículo, se describe el enfoque de la investigación práctica reflexiva del filósofo Anders Lindseth y se discute su relevancia para la formación del profesorado. Para ello, se presentan y se investigan a fondo los aspectos teóricos y metodológicos centrales de este enfoque de investigación. Por medio de estudios de casos ilustrativos, se dan ejemplos de cómo esta aproximación es de utilidad para los estudiantes de educación para desarrollar la competencia investigadora. Asimismo, este trabajo examina cómo el maestro 
puede reflejar su propia práctica, en términos de autoestudio, para aprender de la experiencia y desarrollarse hacia la llamada phronesis (sabiduría práctica o prudencia).

Palabras clave: investigación de práctica reflexiva, formación docente, alumno docente, Filosofía Aplicada, phronesis

\section{Introduction}

\section{Background}

Today, in many European countries it is part of the curriculum that teacher students acquire research skills during their studies; not only to be able to write their master thesis, but also to be able to contribute to innovation processes and educational projects in the school system. Unlike a conventional researcher, a teacher has a genuine inside-perspective on teaching practice, and hence, possesses valuable resources in terms of first-hand experiences and insights that seem to be vital in order to innovate the education system and to further develop teaching practices ${ }^{1}$. Therefore, acquiring research skills as teacher students appears to be highly relevant for school development as such.

One of the approaches that fosters research in the context of teaching practice is so-called reflective practice research. The term was coined by Anders Lindseth2, a pioneer of philosophical

1 See TILLER, Tom: "Lærerstudenten som forsker" in LEMING, Tove, TILLER, Tom \& ALERBY, Eva (eds.): Forskerstudentene - Larerstudenter $i$ nye roller, Cappelen Damm Akademisk, Oslo, 2016, p. 16.

2 LINDSETH, Anders: "Refleksiv Praksisforskning", in Halås, Catrine Torbjørnsen, Kymre, Ingjerd Gåre, Steinsvik, Kari (eds.): Humanistiske Forskningstilnaerminger til Profesjonspraksis, Gyldendal Akademisk, Oslo, 2017a, p. 15-36. 
practice in Scandinavia ${ }^{3}$ and professor emeritus at the Center for Practical Knowledge, at Nord University in Norway, where he contributed important works to the field of nurse education. According to Lindseth, there is a certain form of knowledge embedded or enclosed in one's own experience, which is fundamentally different from theoretical or factual knowledge, but nevertheless essential for one's professional practice - no matter whether you are a teacher, a nurse, a physician etc. ${ }^{4}$. This knowledge can be unleashed by reflecting on your own experiences as a professional, as a practitioner, so to speak. In other words, the goal of reflective practice research - as the name already indicates - is to reflect on one's own practice in order to improve it, to become better at $\mathrm{it}^{5}$. Improvement in this case, however, does not indicate an increase of smartness, effectiveness or cleverness. To become better, in the context of reflective practice research, rather relates to goodness in a more ethical sense, as we will see in the course of this essay (this aspect will be further explicated in 2 . Theoretical framework in this essay).

If we assume that research is essentially concerned with the development of knowledge, then developing practical knowledge can of course be understood as a form of research too. Developing such knowledge through reflection on practice is not necessarily new. John Dewey, the founding-father of experiential learning ${ }^{6}$ is

${ }^{3}$ LINDSETH, Anders \& SVARE, Helge: "Samtalens plass i et menneskeliv", in Samtiden, nr. 3, 2002.

${ }^{4}$ LINDSETH, Anders: "Forskningens vei - fra livserfaring til en observerbar verden og tilbake til livets virksomheter", in HALÅS, Catrine Torbjørnsen, KYMRE, Ingjerd Gåre, STEINSVIK, Kari (eds.): Humanistiske Forskningstilnaerminger til profesjonspraksis. Oslo: Gyldendal Akademisk, 2017 b, p. 27.

${ }^{5}$ Ibidem, p. 244.

${ }^{6}$ DEWEY, John: Experience and Education, Touchstone, New York, NY, 1997. 
known for his saying "learning by doing", which actually read "learning through reflection on doing"?

To a certain degree, also the Community of Inquiry concept by Mathew Lipman ${ }^{8}$ points into a similar direction: A Community of Inquiry can be described as a form of discovery learning, where investigating a topic together with others in a group is at the center (with the emphasis on "together"). The different perspectives that come to the fore in such a group investigation are often based on personal experiences and support a deeper understanding of the examined topic.

Furthermore, also so-called philosophical practice appears to be an influential approach with regards to reflective practice research. In philosophical practice the central method of investigation - the research method, so to speak - is dialogue ${ }^{9}$. And here it has to be mentioned that the term method derives from the term methodos, which consists of two words: "meta" and "hodos". "Meta" can be translated with the English word "over", and "hodos" with the term "way". In that sense a methodos is nothing else than "a way over to something", a way of reflection ${ }^{10}$. In other words, by means of a methodos we can reflect over something that we did in order to make it as good or even better next time - and this does not only include products but also practices - for example teaching practices - and our way of life in general.

7 PATRICK, Felicia: Handbook of Research on Improving Learning and Motivation through Educational Game: Multidisciplinary Approaches, Information Science Reference, Hershey, PA, 2011, p. 1003.

8 LIPMAN, Matthew: Thinking in Education, Cambridge University Press, Cambridge, 2003, p. 84.

${ }_{9}^{9}$ WEISS, Michael Noah (ed.): The Socratic Handbook. Dialogue Methods for Philosophical Practice, LIT publishing, Vienna, 2015.

${ }^{10}$ See LINDSETH, Anders: "Being Ill as an Inevitable Life Topic. Possibilities of Philosophical Practice in Health Care and Psychotherapy", in Weiss, Michael Noah (ed.): The Socratic Handbook. Dialogue Methods for Philosophical Practice, LIT, Vienna, 2015, p. $46 f$. 
And last but not least, so-called participatory action research has to be mentioned. It essentially represents a form of research that is understood not to be done on or for but with people ${ }^{11}$. With people who are directly concerned with the problem or issue under investigation. A basic assumption in this particular action research approach is that those who are concerned with a problem, also possess a genuine knowledge about it. One could call it tacit knowledge, which an outsider, like an external researcher, never would have. The purpose of participatory action research then is to "harness" this knowledge and make it an integral part of the research process.

What distinguishes reflective practice research from participatory action research, is mainly that the latter appears to be more problem-solution oriented. The former is more concerned with deepening one's understanding of a practice and through that deepened understanding, developments are put in motion. Reflective practice research can lead to solutions but it is not solution-oriented in the first place, instead a research process based on this approach can first and foremost be seen as a form of selfreflection. That is, reflective practice research puts the focus on the practitioner and his or her practice, intending that he or she investigates him- or herself with the prospect of gaining selfknowledge and in that way becomes better as a professional ${ }^{12}$.

11 REASON, Peter \& BRADBURY, Hilary: "Introduction. Inquiry \& Participation in Search of a World Worthy of Human Aspiration", in REASON, Peter \& BRADBURY, Hilary (eds.): The Sage Handbook of Action Research, $2^{\text {nd }}$ ed., Sage, London, 2008, p. 1.

12 LINDSETH, Anders: "Refleksiv Praksisforskning", in Halås, Catrine Torbjørnsen, Kymre, Ingjerd Gåre, Steinsvik, Kari (eds.): Humanistiske Forskningstilnaerminger til Profesjonspraksis, Gyldendal Akademisk, Oslo, 2017a, p. 244f. 
The guiding research question

With that background, the guiding research question of this essay can be formulated as follows: "What are essential theoretical and practical elements of reflective practice research?"

In the course of this essay this question will be examined with the focus on teacher education. The writings of Lindseth will form a central resource in this investigation, just as relevant literature related to teacher education. In addition, my personal experiences and reflections as a teacher educator, who frequently works with this approach, are also taken into account.

\section{Overview}

In order to find possible answers to the guiding question of this essay, we will take a closer look at central theoretical implications of reflective practice research in section 2. Theoretical framework. In the section 3. Method, the methodological dimension of this research approach will be outlined. In section 4. Illustrative case studies, three case studies are presented in order to give concrete ideas on how reflective practice research can be and has been conducted in teacher education. In section 5. Discussion, both the theoretical implications, the methodological dimension as well as the presented cases are discussed. Finally, in section 6. Concluding remarks, possible answers on the guiding research question are suggested and concluding remarks are made about reflective practice research when carried out in teacher education.

\section{Theoretical framework}

As the name already indicates, reflective practice research represents a form of research on practice. How practice can be 
understood in more theoretical terms and what it implies to reflect on it - especially with regards to teacher education and teaching practice - will be investigated in the in the present section.

In his same-named article, Biesta poses the question "How does a competent teacher become a good teacher?"13. A key assumption in this article is that a teacher education which solely focuses on the acquisition of competences, is in danger to turn into nothing but a tick box exercise ${ }^{14}$. The purpose of teacher education then would not be more then to check whether the students achieved everything on the list or not. Though Biesta acknowledges that a teacher student necessarily has to acquire competences, he also claims that these competences would never be sufficient for a student in order to practice what could be called good teaching ${ }^{15}$. In that respect he presents the formula "good teaching $=$ competences + judgement ${ }^{\text {"16. }}$.

\section{Praxis vs. poiesis}

In order to understand what Biesta means with the term judgement, we have to take a closer look at a specific concept from Aristotle about two fundamentally different modes of action ${ }^{17}$.

The first one is called poiesis: Poiesis signifies any activity, which has its goal beyond itself ${ }^{18}$. For example, the goal of building a

${ }^{13}$ BIESTA, Gert: "How Does a Competent Teacher Become a Good Teacher? On Judgement, Wisdom and Virtuosity in Teaching and Teacher Education", in: HEILBRONN, Ruth \& FOREMAN-PECK, Lorraine (eds.): Philosophical Perspectives on Teacher Education, John Wiley \& Sons, West Sussex, 2015, p. 3-20.

${ }^{14}$ See ibidem, p. 4.

${ }^{15}$ See ibidem, p. 5.

${ }^{16}$ Ibidem.

17 ARISTOTLE: The Nicomachean Ethics, Oxford University Press, Oxford, 1980, p. 141f.

18 STAUDE, Detlef: "The Path of Consideration. Philosophical Practice in 
house is not the building process as such, rather the goal is to live in this house. Therefore, poiesis is concerned with what can be called how-to-do knowledge (or simply know-how), which Aristotle called techné. Therefore, poiesis can also be understood as some kind of making-action, since it is based on knowing how to make things, so to speak ${ }^{19}$.

Praxis on the other hand is the kind of activity which has its goal within itself, so to speak ${ }^{20}$. Simple examples for praxis are listening to music or going for a walk - we listen to music or go for a hike because we simply enjoy these activities, and that is it. In other words, praxis is about well-being, however not just in the simple sense of being happy or being satisfied ${ }^{21}$. Praxis is oriented towards the promotion of human flourishing, which Aristotle called eudaimonia. In contrast to poiesis, as some sort of making-action, praxis represents a form of doing-action as well as good action, since it is concerned with what is to be done in a given situation (that is, it is concerned with what would be good to be done in that situation. As such, praxis is not about how-to-do knowledge in the first place, but rather about what-to-do knowledge, which Aristotle

Dialogic Life Accompaniment" in Weiss, Michael Noah (ed.): The Socratic Handbook. Dialogue Methods for Philosophical Practice, LIT publishing, Vienna 2015, p. 42f.

${ }^{19}$ CARR, Wilfred: "What is an Educational Practice", in Journal of Philosophy of Education, 21.2., 1987, p. 163-175.

20 STAUDE, Detlef: "The Path of Consideration. Philosophical Practice in Dialogic Life Accompaniment" in Weiss, Michael Noah (ed.): The Socratic Handbook. Dialogue Methods for Philosophical Practice, LIT publishing, Vienna 2015, p. 42f.

${ }^{21}$ BIESTA, Gert: "How Does a Competent Teacher Become a Good Teacher? On Judgement, Wisdom and Virtuosity in Teaching and Teacher Education", in: HEILBRONN, Ruth \& FOREMAN-PECK, Lorraine (eds.): Philosophical Perspectives on Teacher Education, John Wiley \& Sons, West Sussex, 2015, p. 15. 
called phronesis (a term often translated with practical wisdom or prudence ${ }^{22}$ ).

\section{Phronesis in teacher education}

Before examining the term phronesis closer, let us first refer the concepts of praxis and poiesis to what is commonly understood by the term teaching practice. With the previously outlined concept of praxis, teaching practice appears to receive a new and different connotation. By distinguishing poiesis and praxis we become aware that teaching practices cannot only be about reaching goals which lie beyond these practices. In concrete terms, teaching at school cannot only be about having pupils acquiring knowledge, skills and competences, or preparing them in order to get good grades - as some sort of goals to which the activity of teaching is nothing but a means. Understanding teaching practice in this way, turns it into a poietic activity and it would not deserve the term practice anymore.

Teaching practice in the sense of praxis however, implies that "the ultimate orientation of all education should be the well-being and flourishing of our students" ${ }^{23}$. With this in mind we can return to

22 HANSEN, Finn Thorbjørn: "The Call and Practices of Wonder. How to evoke a Socratic Community of Wonder in Professional Settings", in WEISS, Michael Noah (ed.): The Socratic Handbook. Dialogue Methods for Philosophical Practice, LIT publishing, Vienna, 2015, p. 217-240. Or: HELSKOG, Guro Hansen: Philosophising the Dialogos Way towards Wisdom in Education: Between Critical Thinking and Spiritual Contemplation. Routledge, Abingdon, 2019. Or: HØJLAND, Michael: Udvikling af lederes praktiske visdom - med sarligt fokus på et kropsligt forankret lederskab, 2019. Or: WEISS, Michael Noah: "Phronesis - The Backbone of Philosophical Practice?" in STAUDE, Detlef \& RUSCHMANN, Eckart (eds.): Understanding the Other and Oneself, Cambridge Scholar Publishing, Cambridge, 2018, p. 4-17.

${ }^{23}$ BIESTA, Gert: "How Does a Competent Teacher Become a Good Teacher? On Judgement, Wisdom and Virtuosity in Teaching and Teacher Education", in: 
Biesta's initial question about the difference between a competent teacher and a good teacher. This different lies in the - acquired, or not-yet-acquired - ability to "make judgements about what is educationally desirable. For this teacher needs practical wisdom (phronesis)" 24 . In other words, phronesis can be seen as the ability to do the right thing in a given situation - i.e. the concrete teaching situation - with regards to human flourishing, that is, the good life overall $^{25}$. That is, as a phronetic teacher my overall intention is to foster the flourishing of my students, in whatever I do in my teaching, instead of mere having them reach predefined learning targets. In concrete terms, this is what defines the difference between a competent and a good teacher.

Furthermore, as for example Gallagher has pointed out, phronesis cannot be taught, it can only be learned ${ }^{26}$. It can only be learned since it comes through self-knowledge - "know thyself" as Socrates put it. And self-knowledge cannot be taught ${ }^{27}$. And in order to gain self-knowledge, self-reflection is required, that is, a reflection of my own experiences, my attitudes, my actions and finally, my practices. And it is here, where the starting point of reflective practice research (and also phronesis) is to be found: in reflecting on my own practices (as a teacher, nurse, physician

HEILBRONN, Ruth \& FOREMAN-PECK, Lorraine (eds.): Philosophical Perspectives on Teacher Education, John Wiley \& Sons, West Sussex, 2015, p. 18.

${ }^{24}$ Ibidem.

25 WEISS, Michael Noah: "Phronesis - The Backbone of Philosophical Practice?" in STAUDE, Detlef \& RUSCHMANN, Eckart (eds.): Understanding the Other and Oneself, Cambridge Scholar Publishing, Cambridge, 2018, p. 417.

${ }^{26}$ GALLAGHER, Shaun: Hermeneutics and Education, Suny Press, Albany, NY, 1992, p. 198.

${ }^{27}$ See ibidem. 
etc. $)^{28}$. In this respect it becomes evident why Lindseth distinguishes two types of practice research, namely instrumental practice research and reflective practice research ${ }^{29}$. While the first one is about generating how-to-do knowledge (techné), the second one is concerned with what-to-do knowledge (phronesis), that is, finding orientation in one's professional conduct ${ }^{30}$.

\section{The virtuosity of the teacher}

As indicated in the previous section, reflective practice research is rooted in philosophy in general and in virtue ethics in particular. If we assume, as many Ancient philosophers like Plato or Socrates suggest ${ }^{31}$, that practical wisdom is virtue, then virtue comes with experience - "experience is the fruit of years" claimed Aristotle ${ }^{32}$. Like a musician who develops his or her virtuosity by practicing, it appears to be the same with a teacher intending to develop phronesis. It comes with practice and experience, and the reflection on experience. Consequentially, such a virtue-based approach in teacher education represents an approach that aims at "the formation of educationally virtuous professionals" 33 . And reflective

28 See LINDSETH, Anders: "Forskningens vei - fra livserfaring til en observerbar verden og tilbake til livets virksomheter", in Halås, Catrine Torbjørnsen, Kymre, Ingjerd Gåre, Steinsvik, Kari (eds.): Humanistiske Forskningstilnarminger til profesjonspraksis. Oslo: Gyldendal Akademisk, 2017b, p. 243-259.

${ }^{29}$ See ibidem, p. 246.

${ }^{30}$ See ibidem.

31 GALLAGHER, Shaun: Hermeneutics and Education, Suny Press, Albany, NY, 1992, p. 198f.

32 ARISTOTLE: The Nicomachean Ethics, Oxford University Press, Oxford, 1980, 1142a 6-7.

33 BIESTA, Gert: "How Does a Competent Teacher Become a Good Teacher? On Judgement, Wisdom and Virtuosity in Teaching and Teacher Education", in: HEILBRONN, Ruth \& FOREMAN-PECK, Lorraine (eds.): Philosophical Perspectives on Teacher Education, John Wiley \& Sons, West Sussex, 2015, p. 
practice research can be seen as one of several ways to foster such formation, so to speak ${ }^{34}$.

\section{Method}

In the following section, the methodological dimension of reflective practice research as well as several of this dimension's key aspects are presented. This section will be based on both Lindseth's writings on the subject as well as on experiences that I gained when supervising teacher students in reflective practice research projects.

\section{The research process}

In principle, the actual research process in reflective practice research can be outlined in the form of three steps:

1) making experiences,

2) reflecting on these experiences, and

3) trying to gain (self-)insight into one's practices and experiences.

Important methodological aspects are self-observation, and also observing others and then referring the observed to one's own practice. Here, both forms of observation are meant in a more phenomenological sense ${ }^{35}$. In this respect and in reference to Ricœur $^{36}$, Anders Lindseth introduces an important term with

20.

${ }^{34}$ LINDSETH, Anders: "Forskningens vei - fra livserfaring til en observerbar verden og tilbake til livets virksomheter", in Halås, Catrine Torbjørnsen, Kymre, Ingjerd Gåre, Steinsvik, Kari (eds.): Humanistiske Forskningstilncerminger til profesjonspraksis. Oslo: Gyldendal Akademisk, 2017b, p. 244.

${ }^{35}$ See ibidem, p. 249f.

${ }^{36}$ RICEUUR, Paul: Sprogfilosofi, Vinden, København, 1979, p. 86. 
regards to the second step of research process, called concrete reflection ${ }^{37}$.

\section{Concrete reflection and experiences of discrepancy}

Concrete reflection means that the respective practitioner, i.e. a teacher, a nurse etc., tells or writes about an experience (a "phenomenon", so to speak) and then subsequently asks what this experience might essentially be about ${ }^{38}$. Here it can turn out that the experience represents a so-called experience of discrepancy, that means, that the practitioner has the - often intuitive impression that something in what he or she experienced does not "feel right" 39 .

Let me give a simple example from teaching practice: One plans a lesson with great care and has the impression that he or she is well prepared. When the lesson is then hold, it is far from what the teacher had expected. Wondering about the question "What has happened?" can then be the point of departure for telling and reflecting the experience.

In general, by means of such experiences of discrepancy one can get a better understanding of oneself, one's attitude, values and of how one is, so to speak, and how one is doing. In this process of self-reflection, it appears to be mandatory that one truly intends to get to the bottom of these sometimes quite personal matters. Without an honest and authentic approach to self-reflection, selfknowledge in the sense of a development towards phronesis does not seem to be possible.

\footnotetext{
37 LINDSETH, Anders: "Forskningens vei - fra livserfaring til en observerbar verden og tilbake til livets virksomheter", in Halås, Catrine Torbjørnsen, Kymre, Ingjerd Gåre, Steinsvik, Kari (eds.): Humanistiske Forskningstilnarminger til profesjonspraksis. Oslo: Gyldendal Akademisk, 2017b, p. 247.

38 Ibidem.

39 See ibidem.
} 


\section{Parrhesia}

With respect honesty and authenticity when performing selfreflection, Anders Lindseth refers to the Greek term of parrhesia, which in English is often translated with truth telling ${ }^{40}$. Truth telling here can be understood as some sort of experience-sharing and story-telling, making reflective practice research a narrativebased approach. As mentioned previously, telling about one's experiences or writing them down is a central part of the research process. This part of the research can already be understood as a form of reflection - Ricoeur called it concrete reflection ${ }^{41}$, as mentioned previously. And concrete reflection is seen to be essential for the subsequent critical reflection, as will be explained later $^{42}$.

\section{Best practices}

By introducing the term experience of discrepancy, one might get the impression that only negative experiences can be investigated by means of reflective practice research. This, however, is not the case. Also positive experiences or so-called best practices can be examined by means of this research approach ${ }^{43}$. As the name already indicates, best practices signify practices, which were performed excellently. Why they went so well can be investigated by means of reflection. In this way one can become aware of

\footnotetext{
${ }^{40}$ Ibidem, p. 259.

${ }^{41}$ RICEEUR, Paul: Sprogfilosofi, Vinden, København, 1979, p. 86.

${ }^{42}$ LINDSETH, Anders: "Forskningens vei - fra livserfaring til en observerbar verden og tilbake til livets virksomheter", in Halås, Catrine Torbjørnsen, Kymre, Ingjerd Gåre, Steinsvik, Kari (eds.): Humanistiske Forskningstilnaerminger til profesjonspraksis. Oslo: Gyldendal Akademisk, 2017b, p. 248.

${ }^{43}$ WEISS, Michael Noah \& OHREM, Sigurd: "Philosophical Practice as Action Research. The Socratic Method at Norwegian Folk High Schools" in HASER International Journal for Philosophical Practice, Vol. 7, 2016, p. 161.
} 
central aspects which are important when carrying out a similar practice in the future. At its essence, this seems to be what developing practical wisdom is to be about, namely, to reflect good and bad experiences and see what one can learn from them (about oneself).

\section{Research format}

Another important aspect with regards to the methodology of reflective practice research, appears to be the structure of a research paper. In principle, various formats appear to be suitable in this respect. Lindseth once suggested a research design consisting of (a) concrete reflection, that is, describing one's experience in the form of a case, (b) critical reflection, where one reflects on the essence of the described experience (a guiding question here can be "What is at stake in this experience?"), and (c) theoretical reflection, where the author discusses the insights from the concrete and the critical reflection in the light of relevant theories ${ }^{44}$.

However, also other formats are possible, for example essay writing. In my experience even the so-called IMRaD structure has turned out to be useful. Though, as a philosopher, I am principally critical towards this format, it can give a teacher student a clear idea of how to turn his or her teaching experience into an academic narrative. The format itself usually consists of (1) an introduction, sometimes (2) a part on theory, (3) a description of the used methodology, i.e. self-observation, (4) a presentation of results in terms of different cases, and (5) the reflection and discussion of these cases as well as concluding remarks.

44 LINDSETH, Anders: "Dosenten $i$ et FoU-perspektiv. Refleksiv praksisforskning som en vei mot dosentkompetanse", in BACHKE, Carl Christian \& HERMANSEN, Mads (eds.): $\AA$ satse på dosenter. Et utviklingsarbeid, Cappelen Damm Akademisk, Oslo, 2020, p. $97 \mathrm{f}$. 
In the following three cases are presented in order to give illustrative examples about how reflective practice research can be and has already be done in teacher education.

\section{Illustrative case studies}

Anders Lindseth presents several projects from $\mathrm{PhD}$ and Master students in his publications on reflective practice research ${ }^{45}$. However, not only for graduate students this approach seems to be suitable when conducting research. For undergraduates too, it proved to be an appropriate way in order to become familiar with both research activities as well as with one's professional practice. Over the last years I had the opportunity to supervise about 60 teacher students who carried out projects following a reflective practice research approach. These projects were mainly bachelor theses, $R \& D$ projects, and early research papers. In the following I will present three projects in the form of illustrative cases, which have been conducted by students when working on their bachelor thesis. For reasons of research ethics, the cases have been anonymized.

\section{Case 1}

The first project was carried out by two students who investigated the question "How can we use formative assessment in order to foster pupils" learning?" With this project they intended to become more aware of their own formative assessment practices. By using their own teaching experiences, they wanted to gain insight about how to improve or change these practices. In the course of the project, they examined three teaching situations. The first of them

${ }^{45}$ See i.e. ibidem. 
is about assessing process-oriented writing in terms of giving feedback and practicing teacher-student dialogues. The actual process of investigation was a so-called meta-reflection ${ }^{46}$. Here, the two students reflected on what they said in the respective teaching situation, how they said it and how the pupils responded to it. In terms of outcomes, the students presented insights about how to improve communication when practicing formative assessment.

The second teaching situation examined in this project was about a lesson in which the two students employed what is called station teaching. It was a math lesson, and in their thesis they reflected on their own station teaching approaches in order to figure out whether and why (or why not) they would foster so-called cognitive accommodation processes by means of station teaching. They asked themselves, when they would manage to help their pupils to transcend their current cognitive schemes and when they would not, and why. The insights then, were of more personal nature on the one hand (that is, what did the students learn personally). On the other they were also formulated in more generalized terms, so that they could be of help for other teachers too, when using station teaching.

The third teaching situation dealt with so-called cooperative learning. Here the teacher students examined their own attention (or the absence of attention) and the respective consequences this had on the learning process of their pupils. In the meta-reflection of this case the students became aware of different aspects of their attention and how they could keep it best in teaching situations.

All in all, this bachelor thesis illustrated how teacher students can reflect on themselves and their own teaching practice - not only to improve it, but to grow and develop as professionals. As the topics

\footnotetext{
46 See Weiss, Michael Noah\& Helskog, Guro Hansen: "'They often have AHAmoments': how training teachers to philosophize the Dialogos Way with their students can promote life skills and democratic citizenship in education" in Educational Action Research, 2020, p. $7 \mathrm{f}$.
} 
of the three examined teaching situations show, it often are what one might call "little details" that are investigated by means of reflective practice research. However, in the course of such investigations it turns out that these details are not so little, but in fact essential in order to learn to succeed with certain practices.

\section{Case 2}

In another bachelor thesis a student investigated the question: "When do I have the impression to be a good role model for my pupils?" In this thesis too, the student examined three specific experiences which were related to her role as a teacher. The first was about a visit in the public swimming pool with her own kids. Suddenly and unexpectedly, the teacher met some of her pupils there and she realized that for her pupils she cannot be a different person with a different attitude (involving lower ethical standards, i.e.) outside school.

The second experience dealt with a situation where the teacher student once accidentally broke a classroom rule (by walking into the classroom with brown shoes). She realized that the way she would deal with the situation was decisive in order to keep her integrity as a teacher towards her pupils.

The last experience examined a situation which occurred on a daily basis at the school. It was when the kids had lunch break and when they could go out in the school yard. Almost all of them needed her help with putting on their jackets, gloves and boots etc. The student then describes how often she was tempted to lose her temper in that situation. Luckily this never happened since she always recognized that this would jeopardize her being a good role model. What she realized here was the relevance of so-called stoic calm when being a teacher.

In summary this bachelor thesis reflects on the relevance of a teacher's ethical attitude in everyday situations at the school. 
Furthermore, it points out the significance of a teacher's prudence (that is, phronesis) and how it can be further developed by reflective practice research.

\section{Case 3}

The last bachelor thesis that is present here in the form of an illustrative case, dealt with the question "When do I, as teacher, use good learning strategies for pupils with very poor eyesight?" In order to find possible answers on it, the two students who wrote this thesis too, examined three teaching situations.

The first one investigates ways of how to teach a pupil with almost no eyesight to count and to calculate. For that, a teacher piled up plates, for example one pile with four plates and one with six plates. The pupil could then count the number of plates on each pile by touching (and hence counting) each plate. When the two piles then were put together to one, the pupil could do the same procedure again, and learn that $4+6=10$ (and in that way learn to calculate).

The second and third teaching situation were about lessons on the solar system for which the teacher had prepared styrofoam balls in different sizes (illustrating the different seizes of the planets), and then hanging them on the ceiling of the classroom, like a downscaled micro model of the solar system. In this way all pupils, also the one with poor eyesight, could learn about the seize and position of each planet in the solar system.

In their bachelor thesis, the students concluded that they did not only learn how to adjust their teaching practice for pupils with poor eyesight, but that they also learned how they could integrate tactile sense into their teaching in general in order, for example, to foster abstract thinking.

When it comes to the development of phronesis in teacher education by means of reflective practice research, then these three 
presented cases (4.1.-4-3.) seem to tell us that reflecting on the details of a respective teaching situation and how one might respond to it, are essential in the learning process of a teacher student. Furthermore, these three case studies are not merely about acquiring technical skills in teaching situations (in terms of techné). Rather they are about raising awareness on how one is and how one is doing as a teacher in his or her own teaching practice, and how one can improve and develop as a teacher - not only by acquiring theoretical knowledge, but rather, by generating practical knowledge.

\section{Discussion}

As mentioned in the introduction, the guiding question of this essay reads "What are essential theoretical and practical elements of reflective practice research?". This question will now be at the center of the discussion carried out in this section.

As one could already see in the introduction, reflective practice research differs from other forms of research, basically in terms of its intention. This intention is not only about practitioners becoming researchers (like in participatory action research ${ }^{47}$ ), or about practitioners reflecting their experiences (like in experiential learning ${ }^{48}$ ). Rather this research approach intends to foster a practitioner's capacity of self-reflection. The question that comes up here, is whether reflective practice research still deserves the

47 REASON, Peter \& BRADBURY, Hilary: "Introduction. Inquiry \& Participation in Search of a World Worthy of Human Aspiration", in REASON, Peter \& BRADBURY, Hilary (eds.): The Sage Handbook of Action Research, $2^{\text {nd }}$ ed., Sage, London, 2008, p. 1.

48 PATRICK, Felicia: Handbook of Research on Improving Learning and Motivation through Educational Game: Multidisciplinary Approaches, Information Science Reference, Hershey, PA, 2011, p. 1003. 
name research - or, as has been criticized by some, whether this approach rather resembles a form of therapy ${ }^{49}$ ? In response to that critique, one can righteously claim that the Socratic "Know thyself" and the Socratic dialogues of Plato, which took their point of departure in everyday life experiences, can be understood as the source of origin of Western science and research as such. In other words, reflective practice research appears to be in line with the tradition of Western philosophy. Furthermore, in addition to its obvious phenomenological and hermeneutical elements, reflective practice research follows an approach similar to those known from the academic discipline of philosophical practice. In this discipline, the investigation of one's philosophy of life or one's work philosophy is in the focus ${ }^{50}$. Consequentially, reflective practice research - in terms of research - can be seen as a form of philosophical investigation. And if research in general is understood as a practice that produces new knowledge, then reflective practice research generates practical knowledge.

In this respect Lindseth's differentiation between factual and orientational knowledge can be brought into account, where the latter represents our ability to find orientation, i.e. in life, in one's profession etc. ${ }^{51}$. Self-knowledge obviously represents a form of

49 See LINDSETH, Anders: "Forskningens vei - fra livserfaring til en observerbar verden og tilbake til livets virksomheter", in Halås, Catrine Torbjørnsen, Kymre, Ingjerd Gåre, Steinsvik, Kari (eds.): Humanistiske Forskningstilnaerminger til profesjonspraksis. Oslo: Gyldendal Akademisk, 2017b, p. 246.

${ }^{50}$ See i.e. HELSKOG, Guro Hansen: Philosophising the Dialogos Way towards Wisdom in Education: Between Critical Thinking and Spiritual Contemplation. Routledge, Abingdon, 2019. Or: WEISS, Michael Noah (ed.): The Socratic Handbook. Dialogue Methods for Philosophical Practice, LIT publishing, Vienna, 2015. Or: LAHAV, Ran: Stepping out of Plato's Cave. Philosophical Practice and Self- Transformation, Solfanelli, Chieti, 2016.

51 LINDSETH, Anders: "Refleksiv Praksisforskning", in HALÅS, Catrine Torbjørnsen, KYMRE, Ingjerd Gåre, STEINSVIK, Kari (eds.): Humanistiske 
orientational knowledge, which often offers direction in one's selfdevelopment as a professional, i.e. as a teacher. This direction is about a path of improvement, it is about a way of becoming better not only in the sense of how we are doing something (that would be about techne) but in the way who we are as professionals (which is about our phronetic quality ${ }^{52}$ ). In this respect, especially the second of the presented cases can be mentioned, which investigated a teacher's professional attitude. By means of this case, we can make out an existential as well as ethical dimension as important aspects of investigation in reflective practice research. It appears to be this existential and ethical dimension that makes this research approach a virtue-based approach. Whether the development of a teacher's virtuosity can and should be a part of educational research can of course be put into question. However, when we remember Biesta's "How can a competent teacher become a good teacher?" then the answer to the question, whether virtuosity should be part of educational research, appears to be clear and of utmost importance in teacher education. In other words, when the goal of reflective practice research is to become better as a practitioner, then this has to be understood in the sense of developing towards prudence, and not simply in the sense of an increase of smartness, effectiveness or cleverness. Rather, it is the practitioner as a human being that is addressed here.

In the course of this essay, it was suggested that a competent teacher can become a good teacher through self-reflection and subsequent self-knowledge. However, after supervising about 60

Forskningstilncerminger til Profesjonspraksis, Gyldendal Akademisk, Oslo, 2017a, p. 17.

${ }^{52}$ BIESTA, Gert: "How Does a Competent Teacher Become a Good Teacher? On Judgement, Wisdom and Virtuosity in Teaching and Teacher Education", in: HEILBRONN, Ruth \& FOREMAN-PECK, Lorraine (eds.): Philosophical Perspectives on Teacher Education, John Wiley \& Sons, West Sussex, 2015, p. 18. 
students in reflective practice research projects, my impression was and is that the intention of self-reflection and gaining selfknowledge appears to be quite challenging for some students. Often, in the course of such projects, students would drift away from their self-reflective perspective into a more observational perspective. That is, they would not observe themselves in their teaching practices anymore, but they would rather focus on the actions and reactions of their pupils. There is nothing wrong with such a perspective, of course. However, this - often unintended change of perspective appears to be the turning point where a true praxis can turn into mere poiesis. With a poietic perspective we are tempted to acquire techniques and skills in order to find solutions and quick fixes for certain problems in the classroom. And for sure, one cannot and should not deny the importance of finding solutions to concrete problems, of generating how-to strategies and of knowhow in education. However, this is not what reflective practice research actually was developed for $^{53}$. It is not about acquiring techné, it is not about generating how-to-do knowledge in the first place. Rather, in the context of teacher education, it intends the development of phronesis in the sense of the awareness or mindfulness ${ }^{54}$ of a teacher by which he or she can foster human flourishing with both his or her pupils and him- or herself ${ }^{55}$. In an

${ }^{53}$ LINDSETH, Anders: "Forskningens vei - fra livserfaring til en observerbar verden og tilbake til livets virksomheter", in Halås, Catrine Torbjørnsen, Kymre, Ingjerd Gåre, Steinsvik, Kari (eds.): Humanistiske Forskningstilnaerminger til profesjonspraksis. Oslo: Gyldendal Akademisk, 2017b, p. 243.

54 WEISS, Michael Noah: "Philosophical Mindfulness. An Essay about the Art of Philosophizing" in HASER - International Journal of Philosophical Practice, Vol. 8, 2017.

${ }_{55}$ BIESTA, Gert: "How Does a Competent Teacher Become a Good Teacher? On Judgement, Wisdom and Virtuosity in Teaching and Teacher Education", in: HEILBRONN, Ruth \& FOREMAN-PECK, Lorraine (eds.): Philosophical Perspectives on Teacher Education, John Wiley \& Sons, West Sussex, 2015, p. 20. 
educational context, this kind of human flourishing seems to be relatable to what is called self-formation, which in ancient Greece was called paideia ${ }^{56}$. Paideia, as the origin of the word pedagogy, can be understood as the cultivation of the human being and it once signified the development of existential and ethical attitudes, values and their practice.

It is clear that teaching practice, understood as a praxis, receives a different connotation in contrast to poietic actions. Teaching practice seen in the light of praxis is about good actions in the sense of wise actions. And these wise actions can be summarized by the quality or the capability of the teacher, in order to do the right thing in the given situation with regards to living a good life overall (which of course does not only involve the (work) life of the teacher but also those of his or her pupils.) Such a perspective in terms of human flourishing - on education in general and teacher education in particular, is ultimately connected with the virtuosity of a teacher, as it seems. And virtuosity, in the sense of phronesis and self-knowledge, cannot be taught, as pointed out previously. Finally, each teacher (student) has to develop towards phronesis on his or her own; but in order to offer a supportive framework for that task, reflective practice research appears to be a viable option, so to speak.

\section{Concluding remarks}

In this essay we took a closer look at the intentions of reflective practice research which is a form of research that puts the focus on the researcher, in terms of self-reflection. The guiding question, "What are essential theoretical and practical elements of reflective

56 HADOT, Pierre: Philosophy as a Way of Life. Spiritual Exercises from Socrates to Foucault, Blackwell Publishing, Oxford, 2010, p. 102. 
practice research?" can now find at least some temporary answers. The research process of projects in teacher education can be described in three steps: 1) making experiences in the classroom, 2) telling or writing about these experiences and then reflecting on them, and 3) trying to gain (self-)insight into one's own teaching practice. In the course of this essay, it was pointed out that selfinsight and self-knowledge can be acquired through experience. Subsequently, this can lead to the development of phronesis, that is, practical wisdom. Practical wisdom differs from pure practical knowledge since it does not deal with how-to-do knowledge. Rather - in educational contexts - it deals with the question "What to do in a given teaching situation with regards to human flourishing?" and it requires self-knowledge ${ }^{57}$. For teacher students, the prerequisite self-reflection can appear to be new and different from what they know from their previous studies. Nevertheless, reflective practice research in terms of self-studies appears to offer a fruitful way, not in order to educate solely competent teachers but in order to support teacher students to become $\operatorname{good}^{58}$.

\section{References}

ARISTOTLE: The Nicomachean Ethics, Oxford University Press, Oxford, 1980.

BIESTA, Gert: "How Does a Competent Teacher Become a Good Teacher? On Judgement, Wisdom and Virtuosity in Teaching and Teacher Education", in: HEILBRONN, Ruth \& FOREMAN-

${ }^{57}$ BIESTA, Gert: "How Does a Competent Teacher Become a Good Teacher? On Judgement, Wisdom and Virtuosity in Teaching and Teacher Education", in: HEILBRONN, Ruth \& FOREMAN-PECK, Lorraine (eds.): Philosophical Perspectives on Teacher Education, John Wiley \& Sons, West Sussex, 2015, p. 3-20.

${ }^{58}$ Ibidem. 
PECK, Lorraine (eds.): Philosophical Perspectives on Teacher Education, John Wiley \& Sons, West Sussex, 2015, p. 3-20.

CARR, Wilfred: "What is an Educational Practice", in Journal of Philosophy of Education, 21.2., 1987, p. 163-175.

DEWEY, John: Experience and Education, Touchstone, New York, NY, 1997.

GALLAGHER, Shaun: Hermeneutics and Education, Suny Press, Albany, NY, 1992.

HADOT, Pierre: Philosophy as a Way of Life. Spiritual Exercises from Socrates to Foucault, Blackwell Publishing, Oxford, 2010. HANSEN, Finn Thorbjørn: "The Call and Practices of Wonder. How to evoke a Socratic Community of Wonder in Professional Settings", in WEISS, Michael Noah (ed.): The Socratic Handbook. Dialogue Methods for Philosophical Practice, LIT publishing, Vienna, 2015, p. 217-240.

HELSKOG, Guro Hansen: Philosophising the Dialogos Way towards Wisdom in Education: Between Critical Thinking and Spiritual Contemplation. Routledge, Abingdon, 2019.

HØJLAND, Michael: Udvikling af lederes praktiske visdom - med sarligt fokus på et kropsligt forankret lederskab, 2019, available in https://www.eaviden.dk/wp-content/uploads/2019/05/Udvikling-aflederes-praktiske-visdom.ARTIKEL.FINAL_.161019.pdf (last access December $17^{\text {th }}$ 2019).

LAHAV, Ran: Stepping out of Plato's Cave. Philosophical Practice and Self-Transformation, Solfanelli, Chieti, 2016.

LINDSETH, Anders: "Being Ill as an Inevitable Life Topic. Possibilities of Philosophical Practice in Health Care and Psychotherapy", in Weiss, Michael Noah (ed.): The Socratic Handbook. Dialogue Methods for Philosophical Practice, LIT, Vienna, 2015, p. 45-66.

LINDSETH, Anders: "Refleksiv Praksisforskning", in Halås, Catrine Torbjørnsen, Kymre, Ingjerd Gåre, Steinsvik, Kari (eds.): 
Humanistiske Forskningstilnarminger til Profesjonspraksis, Gyldendal Akademisk, Oslo, 2017a, p. 15-36.

LINDSETH, Anders: "Forskningens vei - fra livserfaring til en observerbar verden og tilbake til livets virksomheter", in HALÅS, Catrine Torbjørnsen, KYMRE, Ingjerd Gåre, STEINSVIK, Kari (eds.): Humanistiske Forskningstilnarminger til profesjonspraksis. Oslo: Gyldendal Akademisk, 2017b, p. 243-259.

LINDSETH, Anders: "Dosenten i et FoU-perspektiv. Refleksiv praksisforskning som en vei mot dosentkompetanse", in BACHKE, Carl Christian \& HERMANSEN, Mads (eds.): $\AA$ satse på dosenter. Et utviklingsarbeid, Cappelen Damm Akademisk, Oslo, 2020, p. 75-101.

LINDSETH, Anders \& SVARE, Helge: "Samtalens plass i et menneskeliv", in Samtiden, nr. 3, 2002.

LIPMAN, Matthew: Thinking in Education, Cambridge University Press, Cambridge, 2003.

PATRICK, Felicia: Handbook of Research on Improving Learning and Motivation through Educational Game: Multidisciplinary Approaches, Information Science Reference, Hershey, PA, 2011.

REASON, Peter \& BRADBURY, Hilary: "Introduction. Inquiry \& Participation in Search of a World Worthy of Human Aspiration", in REASON, Peter \& BRADBURY, Hilary (eds.): The Sage Handbook of Action Research, $2^{\text {nd }}$ ed., Sage, London, 2008, p. 113.

RICEUR, Paul: Sprogfilosofi, Vinden, København, 1979.

STAUDE, Detlef: "The Path of Consideration. Philosophical Practice in Dialogic Life Accompaniment" in Weiss, Michael Noah (ed.): The Socratic Handbook. Dialogue Methods for Philosophical Practice, LIT publishing, Vienna 2015, p. 35-44.

TILLER, Tom: "Lærerstudenten som forsker" in LEMING, Tove, TILLER, Tom \& ALERBY, Eva (eds.): Forskerstudentene Larerstudenter $i$ nye roller, Cappelen Damm Akademisk, Oslo, 2016, p. 15-21. 
WEISS, Michael Noah (ed.): The Socratic Handbook. Dialogue Methods for Philosophical Practice, LIT publishing, Vienna, 2015. WEISS, Michael Noah \& OHREM, Sigurd: "Philosophical Practice as Action Research. The Socratic Method at Norwegian Folk High Schools" in HASER - International Journal for Philosophical Practice, Vol. 7, 2016.

WEISS, Michael Noah: "Philosophical Mindfulness. An Essay about the Art of Philosophizing" in HASER - International Journal of Philosophical Practice, Vol. 8, 2017.

WEISS, Michael Noah: "Phronesis - The Backbone of Philosophical Practice?" in STAUDE, Detlef \& RUSCHMANN, Eckart (eds.): Understanding the Other and Oneself, Cambridge Scholar Publishing, Cambridge, 2018, p. 4-17.

Weiss, Michael Noah\& Helskog, Guro Hansen: “"They often have AHA-moments': how training teachers to philosophize the Dialogos Way with their students can promote life skills and democratic citizenship in education" in Educational Action Research, 2020, DOI:10.1080/09650792.2020.181174 


\section{COMENTARIOS, INFORMES Y ENTREVISTAS}

\section{STUDIES, REPORTS AND INTERVIEWS}


